\title{
FIGHTING ON THE OCEAN BLUE: NEW ZEALAND'S EXTRA- TERRITORIAL JURISDICTION AND MARITIME PROTEST
}

\author{
Timothy Smith*
}

In this article the author discusses New Zealand's extra-territorial jurisdiction over criminal acts which occur in the course of protest on the high seas. In particular, the jurisdictional provisions of the Crimes Act 1961 and the Maritime Crimes Act 1999 are analysed for consistency with international norms and for their value in deterring incidents of violence. The author concludes that, while imperfect, the current structure for asserting extra-territorial jurisdiction is perhaps the most convenient given the uncertainty inherent in jurisdictional assertions.

\section{INTRODUCTION}

Two Greenpeace activists in an inflatable boat were today dragged half way up the stern ramp of a Japanese whaling ship ... the crew on board the Nisshin-maru used a long handled flensing knife - normally used for sectioning whales - to cut the inflatable boat from the tow line, sending it shooting back down the ramp.

Greenpeace Press Release, 12 January $2000^{1}$

Incidents of violence between maritime protestors and their quarry are becoming increasingly common. Many of these protests result in acts of violence which threaten human life. Had these incidents occurred on land, criminal sanction would be almost inevitable. Yet at sea, protestors and their quarry appear to act with relative impunity from criminal sanction. This distinction must be viewed as somewhat doubtful, given that the danger caused by such acts can only be greater in the maritime environment.

* Submitted in fulfilment of the LLB(Hons) requirements at Victoria University of Wellington in 2000

1 "Major Escalation in Campaign to Stop Illegal Japanese Whaling" (12 January 2000) Greenpeace Press Release $<$ http: / / www.greenpeace.org/ oceans $>$ (last accessed 3 April 2000). 
This article investigates the possibility of a legal response against such acts of violence, in particular, New Zealand's extra-territorial jurisdiction over such protest incidents. ${ }^{2} \mathrm{New}$ Zealand's environmental policies mean that its territorial waters are not often the scene of protest over whaling, commercial fishing and nuclear power. However, it is an interested party in the peaceful order of the sea. New Zealand has responsibility for marine search and rescue over an area of six million square miles of ocean. ${ }^{3}$ Deterring incidents that may create the need for rescue should therefore be of interest to the New Zealand authorities. The criminal law may provide such a deterrent.

The first part of this paper examines the extent of New Zealand's current extraterritorial jurisdiction over maritime incidents, and the issues that arise from the various statutory provisions read against the background of international law. The second part asks whether extra-territorial jurisdiction could be operated more satisfactorily.

\section{THE OPERATION OF NEW ZEALAND'S EXTRA-TERRITORIAL JURISDICTION}

New Zealand has two statutes that appear to assert, independently, extra-territorial criminal jurisdiction: the Maritime Crimes Act 1999, and the Crimes Act 1961. ${ }^{4}$

Any assertion of jurisdiction over maritime incidents outside territorial waters must inevitably deal with the interface between domestic and international law. Treaties are not enforceable in domestic courts unless incorporated into domestic legislation. ${ }^{5}$

2 New Zealand asserts complete jurisdiction in criminal matters over acts and omissions that occur within New Zealand: Crimes Act 1961, s 5. New Zealand, as defined by the Crimes Act, includes all waters within the outer limits of the Territorial Sea of New Zealand. These outer limits are defined as 12 nautical miles seaward from the nearest point of the base line by the Territorial Sea and Exclusive Economic Zone Act 1977, s 3. See also the United Nations Convention of the Law of the Sea (1982) 21 ILM 1261 [UNCLOS].

3 Sellers v Maritime Safety Inspector [1999] 2 NZLR 44, 49 (CA) per Keith J [Sellers].

4 The Summary Proceedings Act 1954, s 3(1)(a) excludes s 8 of the Crimes Act 1961 from the jurisdictional provisions of the Crimes Act applicable to summary offences. Section 408 of the Maritime Transport Act 1994 states that all offences against that Act are punishable on summary conviction. Moreover, the Crimes Act 1961, s 8(7) states that "Nothing in this section shall apply with respect to any crime against the Shipping and Seaman Act 1952". Pursuant to Acts Interpretation Act 1999, s 22(2). This should be read as the Maritime Transport Act 1994.

5 Attorney General for Canada v Attorney General for Ontario [1937] AC 326 (PC). 
Customary law is part of the common law, ${ }^{6}$ but is thus subject to legislation. ${ }^{7}$ However, there can be no doubt that international law in any case remains extremely influential: ${ }^{8}$

New Zealand Courts have for over a century made it plain that legislation regulating maritime matters should be read in the context of the international law of the sea and, if possible, consistently with that law.

The case for adherence to international law when asserting extra-territorial jurisdiction is strong. Assertions of jurisdiction over such incidents occur outside of the sovereignty inherent over territorial waters. There is an increased risk of stepping on the juridical toes of other nations.

Thus, before providing an analysis of the application of each of the domestic provisions to maritime protest incidents, it is necessary to enter a brief discussion of what constitutes the relevant international law.

\section{A Extra-Territorial Jurisdiction in International Law}

Most protest incidents outside territorial waters occur on the "high seas". 9 The high seas are "reserved for peaceful purpose" by article 94 of the United Nations Convention on the Law of the Sea (UNCLOS). ${ }^{10}$

Maritime protest incidents are problematic to deal with in international law. International criminal law is usually concerned with extremely serious crimes such as terrorism, piracy and other 'crimes against humanity'. ${ }^{11}$ With such crimes, the common interest amongst states in repression is manifest. Importantly, such is the seriousness of

$6 \quad$ Triquet $v$ Bath (1764) 3 Burr $1478(\mathrm{~KB})$.

7 Chung Chi Cheung v The King [1939] AC 160, 167 (PC).

8 Sellers, above n 3, 57 Keith J.

9 The high seas are defined, for the purposes of this paper, as those waters that are not included in the territorial sea of a state. This is not the definition accorded to the term in UNCLOS, art 86 . UNCLOS further sections the ocean into Contiguous Zones and Exclusive Economic Zones which extend up to 200 nautical miles from the baseline of the coastal state: UNCLOS, art 57 . The "high seas" as defined by UNCLOS include only areas outside those zones: UNCLOS, art 86. However, these zones are, as the name suggests, based on economic objectives. The relevant international law for this paper which is applicable to the high seas also applies to the Exclusive Economic Zone: UNCLOS, art 58.

10 United Nations Convention of the Law of the Sea (1982) 21 ILM 1261. There has been some doubt cast on the authority of UNCLOS, however it is clear that in New Zealand at least it is considered to be declaratory of customary international law: Sellers, above n 3, 47 per Keith J.

11 UNCLOS, art 97, deals with the repression of piracy. The Rome Convention deals with the repression of terrorism. 
such offences that international action to provide effective deterrents and remedies will often follow a single incident. ${ }^{12}$ Protest incidents, being generally less serious in nature, if more commonplace, do not appear to create such impetus in the international community for repression. It is even questionable whether there is a shared desire to deter and prosecute protesters: because protests often have a political component, different states may view them differently.

The direct consequence of this is that there are no specific international instruments tailored to the difficulties presented by protest incidents. More crucially, the relevant customary law is not easily applied to protest incidents. These incidents are distinct from the paradigmatic crimes at seas, and present some complex features.

Apart from extreme examples such as piracy, international law has developed mainly to deal with "intra-ship" incidents: those that occur on board a single ship. ${ }^{13}$ Jurisdictional law has developed in which the nationality of the vessel is significant. This presents difficulties with respect to protest incidents as they generally involve violence that occurs between the passengers or crew of one ship and the passengers or crew of another ship. An incident that occurs between ships of two nationalities will complicate jurisdictional issues.

Vessels upon the high seas are subject to the exclusive enforcement jurisdiction of the Flag State, that is, the state in which the ship is registered. ${ }^{14}$ Save for certain limited exceptions, ${ }^{15}$ no state other than the Flag State can take enforcement actions against the ship, for instance by boarding the ship to investigate a crime or to make an arrest.

However, the Flag State does not have exclusive prescriptive jurisdiction over ships on the high seas. ${ }^{16}$ Prescriptive jurisdiction refers to the ability of a state to prescribe, or define, an incident as coming within that state's jurisdiction. Thus, "it is of course possible for the legislature of New Zealand to enact laws which relate to certain events occurring ...

12 For instance, the terrorist seizure of the Achille Lauro during which a United States' national was killed provided the impetus for the 1988 Convention for the Suppression of Unlawful Acts Against the Safety of Maritime Navigation (the Rome Convention), on which the Maritime Crimes Act 1999 is based.

13 For example, if a crew member of a fishing vessel fires a flare at protestors on board an inflatable craft, that is an inter-ship incident. This may be contrasted with the "usual" intra-ship incident of one crew member firing a rifle at another crew member on board the same ship.

14 UNCLOS, art 92(1).

15 For an analysis of exceptions to flag-state jurisdiction, see Robert C F Reuland "Interference with Non-National Ships on the High Seas: Peacetime Exceptions to the Exclusivity Rule of Flag-State Jurisdiction" (1989) 22 V and J Transnat'l L 1161.

16 Geoffrey Marston "Crimes by British Passengers on Board Foreign Ships on the High Seas" (1999) CLJ 171 . 
on foreign ships."17 Of course, a state cannot take enforcement measures against ships on the high seas that do not fly its flag, thus: ${ }^{18}$

Whatever the extent to which a state asserts criminal jurisdiction ... since the state cannot

exercise its sovereign power in a foreign state, it must normally await the return of [the

offender] ... before it can take effective steps to exercise its jurisdiction over them.

Prescriptive criminal jurisdiction is generally asserted on five grounds. ${ }^{19}$ States may legislate for their own territory (the territorial principle), and for acts that have effects on that territory (the objective territorial principle). They may legislate for the actions of their nationals abroad (the nationality principle), against acts that threaten the security of the state (the protective principle) and against acts where the victim is a national of the state (the passive personality principle). Finally, states may legislate for certain crimes on the basis that the crime offends against some universal standard (the universality principle).

Some grounds are more accepted by the international community than others. This may influence the enforcement of laws asserting extra-territorial jurisdiction. While most states would feel comfortable in asserting jurisdiction based on either the territorial or nationality principles, other factors, including diplomatic considerations, may become more relevant where the principle itself is less self-sustaining. This may work against the assertion of jurisdiction over protest incidents; it is easier to assert doubtful jurisdiction over incidents that other states express no interest in, ${ }^{20}$ than incidents which arouse international attention.

It must therefore be concluded that international law, as it applies to the jurisdictional issues posed by protest incidents, is an imperfect tool with which to fashion an effective deterrent. It is with this background in mind that the provisions of the Crimes Act 1961 and the Maritime Crimes Act 1999 must be considered.

\section{B The Crimes Act 1961}

If New Zealand is to assert jurisdiction over maritime incidents, it is crucial that the Crimes Act, which contains the majority of New Zealand's criminal code, has robust and effective extra-territorial jurisdiction provisions.

17 Sellers, above n 3, 49 Keith J. See, for international authority, The SS Lotus (France v Turkey) (1927) PCIJ Ser A no 10 [The SS Lotus].

18 Sir Robert Jennings QC and Sir Arthur Watts QC (eds) Oppenheim's International Law (9 ed, Longman Group, Harlow (Essex), 1992) 463.

19 Ian Browlie Principles of Public International Law (5 ed, Oxford University Press, Oxford, 1998) 306307.

20 See, for example, United States v Roberts (1998) 1 Fed Supp (2d) 601 (ED Lou) per Vance J. 
The extra-territorial jurisdiction of the Crimes Act is provided for in section 8. Broadly, New Zealand asserts jurisdiction in three cases:

(1) where the act or omission occurs on board a Commonwealth ship (section 8(1)(a));

(2) where the offender is a British subject on board any foreign ship, to which they do not belong, on the high seas (section $8(1)(d))$;

(3) where the offender arrives in New Zealand in the course of or at the end of a journey during which the offence was committed (section $8(1)(\mathrm{c}))$.

Jurisdiction is also asserted by section 8(3) over any person who has belonged to any Commonwealth ship within three months prior to the offence.

\section{Jurisdiction over Commonwealth ships and British subjects}

At first blush sections 8(1)(a) and 8(1)(d) contain reasonably straightforward assertions of nationality-based jurisdiction. ${ }^{21}$ However, the assertion is clumsily made, involving both over-extensions of and questionable exclusions from New Zealand's extra-territorial jurisdiction in international law .

Jurisdiction is asserted by sections 8(1)(a) and (d) over all British subjects who commit crimes on vessels to which they do not belong, and all Commonwealth ships. While this will include New Zealand nationals and New Zealand ships it will also include ships and persons of other nationalities. The extension is based on a Commonwealth Agreement made in 1931 to enable Commonwealth members to assert jurisdiction over "offences committed on board ships registered in any Part of the Commonwealth."22 The reciprocal arrangement effectively supplemented New Zealand's customary jurisdiction. However, New Zealand withdrew from the Agreement on 29 September 1979. 23 New Zealand's continued assertion of jurisdiction over other Commonwealth nationalities based on this agreement is therefore inappropriate.

Moreover, in two respects New Zealand fails to assert its potential nationality based jurisdiction. First, while it is an occasional tactic of protesters to jump into the water to

21 If New Zealand did not assert flag-based jurisdiction over its vessels, it would be in breach of the commitments contained in UNCLOS, arts 94(2)(b) and 97(1).

221931 British Commonwealth Merchant Shipping Agreement (1932) 129-130 League of Nations Treaty Series 2961, art 23.

23 (1979) 1214 UNTS 474. Withdrawal noted in Department of Foreign Affairs "Report of the Department of Foreign Affairs" [1979] AJHR A1, 38. 
attempt to divert fishing vessels, ${ }^{24}$ the provisions refer to crimes committed "on board" a ship thereby excluding those who commit crimes whilst in the water.

More importantly, in the protest context, New Zealand excepts from its jurisdiction those nationals on board a foreign ship "to which he belongs". "Belonging" has been interpreted by the House of Lords to mean a member of the crew, ${ }^{25}$ irrespective of the duration of the stay on board. ${ }^{26}$ The "belongs" exclusion is potentially significant in that it is the nature of the ships that participate in such incidents that almost all persons involved could be described as "crew", and therefore "belong" to their respective vessels. This is especially the case with any target ship that "fights back", but also with protest vessels. Thus, jurisdiction could not be asserted through section $8(1)(d)$ even if they were New Zealand nationals. This distinction does not exist in international law.

Both the over-extensions and exclusions outlined above are symptomatic of the general problem with the Crimes Act jurisdictional sections, the age of the provisions. The provisions are modelled on the provisions of the English Merchant Shipping Act 1894 (UK), ${ }^{27}$ with little change. International law has developed. That the jurisdictional provisions have not been re-evaluated to acknowledge international developments is unsatisfactory.

\section{Jurisdiction over arrivals and section 8(3)}

The assertions of extra-territorial jurisdiction contained in sections 8(1)(c) and 8(3) are more fundamentally problematic: neither provision sits easily with established jurisdictional grounds in international law. Section 8(3) is perhaps the more troublesome in this regard. ${ }^{28}$ Historically an instrument for controlling the activities of merchant sailors while they waited in foreign ports for the arrival of their ship, ${ }^{29}$ it was removed from the jurisdictional provisions of the Crimes Bill 1989. Again, its continued presence in the face

24 See, for example "Major Escalation in Campaign to Stop Illegal Whaling" (12 January 2000) Greenpeace Press Release <http://www.greenpeace.org/ oceans> (last accessed 3 April 2000): six activists jumped into sub-zero waters to divert a Japanese whaler.

$25 R v$ Kelly [1982] AC 665 (HL). This is extremely persuasive authority, given that the jurisdictional provisions of the Crimes Act are modelled on the provision interpreted in that case, s 686 of the Merchant Shipping Act (UK).

$26 R v$ Kelly [1982] AC 665, 678 (HL) per Lord Roskill.

27 For analysis of the history of New Zealand's s 8, see SJ Shields "Out of Sight - Out of Mind? Extraterritorial Jurisdiction" (LLM Research Paper, Victoria University of Wellington, 1981).

28 See Shields, above n 27, 21; Hon Bruce Robertson (ed) Adams on Criminal Law (Brookers, Wellington, 1992), Crimes Act, CA400.04 (updated 7 May 1999).

29 Shields, above n 27, 21. 
of international law developments is symptomatic of the lack of re-evaluation of the jurisdictional provisions.

Section $8(1)(\mathrm{c})$ is less easy to dismiss as an historical anachronism. ${ }^{30}$ It was recognised, at least up until 1989, as a "legitimate" assertion of jurisdiction. ${ }^{31}$ Section 8(1)(c) appears to assert jurisdiction on the basis that the offender is present in New Zealand. While the presence of the offender within the territory of a state is a basis for the state to enforce its jurisdiction, this begs the question of what jurisdiction is to be enforced. ${ }^{32}$ Enforcement jurisdiction is not self-perpetuating; prescriptive jurisdiction over the incident is also required. In itself, therefore, the section cannot be said to prescribe a "legitimate" jurisdiction.

Rather, section 8(1)(c) derives its legitimacy from the requirement, contained in section 400 of the Crimes Act, that the Attorney-General consent to the prosecution of any offence committed beyond New Zealand on board a non-New Zealand ship. Where consent is not obtained, any conviction will be quashed. Consent is presumed at trial in the absence of objection, although it remains open for the accused to take the point on appeal. ${ }^{33}$ Although consent is required to prosecute, an offender who comes within one of the above provisions will still be able to be arrested, and remanded in custody. ${ }^{34}$

The consent of the Attorney-General acts to legitimise jurisdictional assertions in two ways. First, section 400 requires that, where jurisdiction is asserted only on the basis of section 8(1)(c), the Attorney-General "shall not give his consent unless he is satisfied that the Government of the country to which the ship ... belongs has consented to the institution of proceedings". Thus, the assertion of jurisdiction is legitimised in international law in that the Flag State, which has jurisdiction over the incident by virtue of the nationality of the ship on which the crime was committed, transfers its jurisdiction by specific agreement to New Zealand. In many respects the assertion made by New Zealand in such cases is one of universal jurisdiction: by consenting to New Zealand's prosecution

30 Section $8(1)$ (c) is slightly unusual in that, unlike the rest of s 8 , it is not based on the Merchant Shipping Act 1984 (UK), s 686. That Act does not provide for jurisdiction over those who commit a crime on any ship that later arrives in the territory in the course of the journey during which the act was committed. Rather, s 8(1)(c) was amended in Select Committee to make the law the same as that in the Canadian Criminal Code: Hon J R Hanan (1961) 328 NZPD 2207.

31 Crimes Bill 1989, no 152-1, Explanatory Note. Compare this with the treatment of s 8(3), which was deleted from the 1989 Bill.

32 See, for example $R v$ Dodd (1874) 2 NZCA 598.

33 Hon Bruce Robertson (ed) Adams on Criminal Law (Brookers, Wellington, 1992), Crimes Act, CA314.05 (updated 7 May 1999).

34 Crimes Act 1961, s 400(1); Maritime Crimes Act 1999, s 17(2). 
of the offence, the Flag State is recognising both that the incident is worthy of criminal sanction and that it is expedient that New Zealand prosecute.

More generally, it is submitted that the Attorney-General cannot give consent to prosecute where prescriptive jurisdiction does not exist. Thus, the consent provision imports a requirement of consistency with international law into the prescriptive provisions, ensuring that any prosecution will be legitimate.

In giving consent, the Court of Appeal has held that the Attorney-General will "usually consider the implications of the prosecution outside New Zealand ." ${ }^{35}$ This can be taken to include both matters of comity and also the more general question of whether New Zealand has jurisdiction in international law. International law is a relevant consideration in making the decision whether to give consent. ${ }^{36}$

That the Attorney-General must consider international law does not mean that the Attorney-General is bound by international law. However, it is clear that the New Zealand courts are prepared to interpret maritime legislation to impose such limitations upon broad discretionary powers. ${ }^{37}$

In the leading case, Sellers $v$ Maritime Safety Inspector, the Court of Appeal held that the discretionary power of the Director of Maritime Safety to place safety requirements on departing pleasure craft had to" be exercised in accordance with the relevant rules of international law." 38 This was despite the relevant provision in the Maritime Transport Act making no express mention of such a limit, and the discretion being based on a subjective standard.

The Court indicated that statutes ought "never to be construed to violate the law of nations if any other possible construction remains." 39 In the case of broad discretionary powers, a construction consistent with international law will almost always be available. Sellers provides authority for 'glossing' a limitation based on international law into provisions that, although broad, are not particularly ambiguous even if, in the words of one commentator, the "net effect of the Court's gloss ... is to erase [the provision] from the

$35 R v$ Fineberg (No 2) [1968] NZLR 443, 451 (CA) per Turner J.

36 Tavita $v$ Minister of Immigration [1994] 2 NZLR 257 (CA). For a successful review of an AttorneyGeneral's decision to consent to a prosecution see Buffier v Brown (1987) 32 A Crim R 214, 218 (FCA) per Neaves J.

37 Sellers, above $\mathrm{n}$ 3. The New Zealand law has apparently diverged from English law on this point: see $R v$ Secretary of State for the Home Department, Ex parte Brind [1991] 1 AC 696 (HL).

38 Sellers, above n 3, 60 per Keith J .

39 Sellers, above n 3, 59 per Keith J. 
statute book."40 The discretion of the Attorney-General in granting consent to prosecute is therefore likely to be constrained by international law.

Of course, the above merely delimitates the capacity of the Attorney-General to consent to prosecute. Consistency with international law will not generally require the AttorneyGeneral to exercise that capacity and consent. Thus, in effect the Attorney-General determines what jurisdiction may be exercised over extra-territorial events, especially through sections $8(1)(\mathrm{c})$ and $8(3)$. This is in contrast to the Attorney-General's role in giving consent to the prosecution of New Zealand nationals who commit crimes on board foreign ships. There, the role is one of comity, ensuring that the two states' competing jurisdictional claims are resolved harmoniously. Whether this approach is satisfactory is discussed in Part Three below.

\section{The Maritime Crimes Act 1999}

The Crimes Act, as it applies to maritime offending, must now be read in light of the provisions of the Maritime Crimes Act 1999. In imagining the arrival of the latter alongside the Crimes Act, it is hard not to conjure the image of a sleek super-yacht pulling up beside a creaky old tug. The Maritime Crimes Act enacts into domestic law the 1988 Convention for the Suppression of Unlawful Acts Against the Safety of Maritime Navigation (the Rome Convention). ${ }^{41}$ Historically an anti-terrorism measure, ${ }^{42}$ it has potential use as a measure against lesser forms of maritime violence.

The jurisdiction asserted by the Maritime Crimes Act enjoys two advantages over the jurisdiction asserted by the Crimes Act. Crucially, the jurisdiction asserted by the Maritime Crimes Act rests on a specific multilateral treaty, a far less ethereal basis than the customary law relied on by the Crimes Act. The jurisdiction on which enforcement measures may be based is therefore far more certain. Moreover, the Act asserts a far broader base of jurisdiction than the Crimes Act. ${ }^{43}$ Even where the offence has no connection with New Zealand, New Zealand will be able to assert jurisdiction where the offender is present in its territory. ${ }^{44}$

40 Paul Myburgh "Shipping Law" [1999] 3 NZLR 387, 398.

41 Convention for the Suppression of Unlawful Acts Against the Safety of Maritime Navigation (1988) 278 ILM 668.

42 Graham Kelly (18 May 1999) 577 NZPD 1642.

43 Rome Convention, art 6(1)(a); Maritime Crimes Act 1999, s 8(1)(a).

44 Rome Convention, art 6(4); Maritime Crimes Act 1999, s 8(3). Importantly, the Convention also provides for the extradition of offenders: Rome Convention, art 7. 
Given that the Maritime Crimes Act is based on a specific international agreement, jurisdiction will always be able to be asserted through the Rome Convention so long as the offence being prosecuted (by virtue of section 4 of the Act) is an offence covered by the Convention (within article 3). This is usually not problematic, as section 4 of the Act is, for the most part, a direct rendition of article 3. There are however, some deviations, two of which have the potential to cause difficulty.

Article 3(1)(b) of the Convention provides that any person commits an offence who "performs an act of violence against a person on board a ship if that act is likely to endanger the safe navigation of that ship". This definition is not directly reproduced in the Act, instead, the relevant provision requires only "an act of violence". ${ }^{45}$ The limitation that the act of violence be directed against "a person" was apparently intended to be imported by defining "act of violence" in terms of certain crimes defined by the Crimes Act $1961 .{ }^{46}$

All of the substantive provisions listed involve acts against a person, except section 198B, which creates additional liability for those who use firearms in the commission of crime. While this will include crimes against persons, it also prima facie includes a substantial number of provisions that do not. For instance, if a whaler, with intent to cause danger to property, shoots a firearm at a protest ship, they commit a crime against section 300 of the Crimes Act and, thus, a crime against section 198B. Such an action is not within the contemplation of Article 3(1)(b) of the Rome Convention as the act is not committed against a person.

Sections 4(1)(e) and (f) of the Maritime Crimes Act also appear to assert a wider jurisdiction than is justifiable. These provisions are concerned with the placement of things on board a ship which are likely to destroy the ship or cause damage to the ship that endangers its safe navigation. The difficulty is created by the use of different words to describe the "things" caught by the provision. The Maritime Crimes Act provides an offence in the case of the placement of "anything", however Article 3(1)(d) provides an offence only in the case of the placement of "a device or substance". Starting with its literal meaning, "anything" is arguably wider than "a device or substance". Biological agents, for example, are neither device nor substance yet fall within "anything".

Neither difficulty is substantial. Most likely, the incongruities can be resolved easily by the Courts applying a Sellers gloss to the provisions. Thus, the word "crime" in 198B could be read as "crime against a person", for the purposes of defining an "act of violence" in the Maritime Crimes Act, and "anything" could be read as "device or substance".

45 Maritime Crimes Act 1999, s 4(1)(b).

46 Maritime Crimes Act 1999, s 2. 
In general, therefore, the issue that arises in applying the provisions of the Maritime Crimes Act to extra-territorial incidents is not jurisdictional, but rather whether a substantive crime has been committed against section 4 of the Act. It is these provisions that contain the main limitations on using the Maritime Crimes Act as a weapon against protest incidents.

Crucially, apart from section 4(1)(a), which deals with the intentional exercise of control over a ship through force or intimidation, the provisions require that the crime committed must be one which is likely to either destroy the ship, or endanger its safe navigation. The Act is therefore unlikely to apply to protest incidents involving actions between two large vessels. Most acts which take place in protest incidents are directed against persons, and are unlikely to endanger the safe navigation of a ship of a large vessel which the target person stands. Firing projectiles at a person on board a large ship does not endanger the safe navigation of the ship, nor does throwing acid at the fishing nets of a ship, even if the actions cause damage which takes significant time to remedy.

The Maritime Crimes Act is more likely to be relevant for incidents involving smaller vessels, such as inflatable pontoon craft. Actions involving small craft are more likely to endanger the safe navigation of the small craft, and hence fall within the provisions of the Act. Thus, if a fishing boat fires a firearm at an inflatable, and a pontoon is punctured, ${ }^{47}$ then that would appear, prima facie, to be damage to the vessel which is likely to endanger its safe navigation. Similarly, if objects are fired around an inflatable craft, so that the crew must concentrate on avoidance of the missiles, then that might be seen as an act likely to endanger the safe navigation of the vessel. In the latter case, however, no crime would be committed as section 4(1)(b) (the only section applicable) requires the offender to be on board the ship which has its safe navigation affected. ${ }^{48}$

A possible issue is that the Act only applies to ships. Ship is defined in section 2 of the Act as meaning "a vessel of any type whatsoever". This would appear, in the ordinary way of things, to include a small craft. A similar definition in the Shipping and Seamen Act 1952 was held (in a case involving a protest incident) to include a kayak. ${ }^{49}$ This technical argument is therefore unlikely to restrict the possible application of the Maritime Crimes Act to instances involving smaller craft.

47 This incident occurred of the coast of Norway against a Greenpeace inflatable: "Whalers Open Fire" (12 July 1999) Greenpeace Press Release <http://www.greenpeace.org/ oceans> (last accessed 3 April 2000).

48 Maritime Crimes Act 1999, s 4(1)(b); Rome Convention, art 3(1)(b).

49 Thompson v Police (21 December 1992) unreported, High Court, Wellington AP 250/92 (HC) per Gallen J. 
The Maritime Crimes Act is therefore a more satisfactory instrument than the Crimes Act with which to assert extra-territorial jurisdiction over protest incidents. It provides a rock on which to fasten a claim of jurisdiction in international law, and is free from the uncertainties associated with the older Act. However, the Maritime Crimes Act will only ever provide jurisdiction over quite serious protest incidents. The provision is based on jurisdiction that the international community has deemed to be necessary to combat serious incidents of terrorism and violence at sea. It is suggested that international reaction might not be positive to an exercise of jurisdiction on the basis of the Rome Convention over incidents that are less serious than was contemplated at its conception.

In ensuring that asserting jurisdiction does not provoke such a response, the role of the Attorney-General is crucial. Section 17(1) of the Maritime Crimes Act provides that "no proceedings for the trial and punishment of a person [charged with a crime against the Act]... can be instituted in any court except with the consent of the Attorney-General." In giving consent, the Attorney-General must be cognisant of international reaction. ${ }^{50}$ The Attorney-General's consent also imports a requirement of comity into the Act. In the case of an offence against the Maritime Crimes Act, up to four countries could claim jurisdiction: clearly, to avoid double jeopardy and to promote international harmony, it is appropriate that each jurisdiction has cognisance of the other competing assertions.

The role of the Attorney-General here is not one of prescribing jurisdiction and implementing international law. It has been argued above, in relation to the Crimes Act, that the requirement of the Attorney-General's consent is just that. It will later be suggested that this may be unsatisfactory. However, in the Maritime Crimes Act, the Attorney-General is not involved in determining prescriptive jurisdiction. What jurisdiction may be enforced is already explicitly provided for by the Act. The role of the Attorney-General is to decide whether New Zealand should enforce jurisdiction in a particular case. This is, arguably, a far more desirable and efficient approach. It is a further reason why, in case of concurrent jurisdiction with the Crimes Act, the Maritime Crimes Act is to be preferred.

\section{IS THE OPERATION OF NEW ZEALAND'S EXTRA-TERRITORIAL JURISDICTION SATISFACTORY?}

New Zealand thus asserts extra-territorial jurisdiction over maritime incidents in three main ways: the Maritime Crimes Act covers certain specific crimes; nationality-based jurisdiction is asserted directly by the Crimes Act; finally, jurisdiction may be asserted in specific instances through section $8(1)(c)$ when the Attorney-General feels there are legitimate grounds for asserting jurisdiction over the incident.

$50 \quad R v$ Fineberg (No 2) [1968] NZLR 443, 451 (CA) per Turner J. 
The effectiveness of these provisions must be judged against two fundamental criteria. First, any assertion of jurisdiction over maritime protest incidents should be made consistently with international law. Events that occur on the high seas occur within an international arena. Care must be exercised to respect this fundamental aspect of the incident. This means having regard to aspects both of comity and of maritime and jurisdictional international law. Second, any provisions must provide relative certainty for enforcement officers. This is a practical consideration. In order for there to be effective enforcement of any jurisdiction, generally officers should be reasonably certain of their rights and responsibilities. If uncertainty leads to a cautious approach on the part of enforcement officers, reluctance to bring prosecutions may effectively render the jurisdiction nugatory.

The second criterion is closely linked to the first. The extra-territorial provisions of the Crimes Act are by themselves tolerably clear. However, uncertainty arises because of the need to act consistently, if possible, with international law. This uncertainty derives from several sources. The application of international law principles to specific facts is ambiguous. Further, the apparent inconsistencies between the literal provisions of the Act and international law create doubt as to how these provisions are to be interpreted, especially in the absence of case authority. Finally, the requirement that the AttorneyGeneral consent to prosecution of certain offences renders the existence of prescriptive jurisdiction unknown at the time enforcement measures are taken.

In comparison, the Maritime Crimes Act 1999 is perhaps a model of how extraterritorial jurisdiction should be asserted. The provisions are direct assertions, with some minor discrepancies, of a specific multilateral treaty. Thus, the relevant international law is clear, and little interpretive doubt arises as few inconsistencies between the provisions and international law exist. Enforcement officers can therefore be reasonably confident about what jurisdiction can be enforced and when. Finally, the requirement that the Attorney-General consent to prosecutions enables a final layer of comity to be laid over the proceedings. The requirement does not itself create uncertainty for enforcement officers as it does not concern the existence of prescriptive jurisdiction.

However, the Maritime Crimes Act is based on a tolerably clear international agreement. The international law that the Crimes Act must contend with is far less precise than the Rome Convention. It is therefore more difficult, if indeed it is possible, to achieve provisions which are both consistent with international law and free from significant doubt as to the grounds on which jurisdiction can be safely enforced.

This paper now turns to the question of how the impact of such doubt can be lessened so as to increase the certainty of enforcement. Barring legislative intervention, such consistency and certainty as can be achieved must be through the requirement of the Attorney-General's consent or judicial interpretation of the jurisdictional provisions. 


\section{A The Consent of the Attorney-General}

The current device for ensuring consistency with international law provided in the Crimes Act is the requirement that the Attorney-General consent to the laying of information for certain offences that may raise jurisdictional issues. It has been suggested in this paper that the Attorney-General must only give consent to lay information when it would be consistent with international law to do so. It is clear that the international law will at least be a relevant consideration in the decision whether to grant consent. ${ }^{51}$

In some respects, this is an ideal method of implementing international law. As a representative of the Government of New Zealand the Attorney-General can both represent the State in liaising with other states who may assert jurisdiction, and be cognisant of international reaction. As a member of the judiciary, the Attorney-General can properly adjudicate on the issue of jurisdiction. Where prosecutions are taken under section $8(1)(\mathrm{c})$, the Attorney-General is the most appropriate functionary to gain consent from the Flag State.

There are difficulties, however, with sole reliance on the Attorney-General to hold the reins of New Zealand's extra-territorial jurisdiction. First, the reins can only be pulled when consent is required by section 400 of the Crimes Act. Excluding instances where section 8(3) has been invoked, the Attorney-General is only required to give consent when the offence was committed on board a non-New Zealand ship. Of course, international law concerns will be most prominent when a foreign vessel is involved, but it is by no means the only instance. The prosecution of foreign nationals who commit crimes on board a New Zealand ship will also raise issues of comity.

Moreover, the Attorney-General's consent is only required for the laying of information of the offence. It does not prevent enforcement agencies conducting investigations on, or arresting, vessels on which crimes have been committed to determine whether information should be laid. ${ }^{52}$ While this makes practical sense in taking timely enforcement measures, such freedom is problematic in international law. Although jurisdiction is, in general, enforceable as soon as the offender comes within the territory of the enforcing state, article 27(5) of UNCLOS provides that: ${ }^{53}$

... the coastal State may not take any steps on board a foreign ship passing through the territorial sea to arrest any person or to conduct any investigation in connection with any

$51 \quad R v$ Fineberg (No 2) [1968] NZLR 443, 451 (CA) per Turner J.

52 Crimes Act 1961, s 400.

53 UNCLOS, art 27(5); see also Brownlie, above n 34, 196. 
crime committed before the ship entered the territorial sea, if the ship, proceeding from a foreign port, is only passing though the territorial sea without entering internal waters.

Thus, enforcement measures taken prior to the Attorney-General's consent being required may still breach international law. Extra-territorial jurisdiction asserted over acts that occur upon foreign ships cannot be enforced in accordance with international law until a vessel enters internal waters. ${ }^{54}$ The Attorney-General is unable, therefore, to always prevent violations of international law.

If consistency cannot always be secured, certainty also does not necessarily follow from the role of the Attorney-General. Although the Attorney-General may be able to implement consistency on a case-by-case basis, the nature of the decision means that predicting whether consent will be forthcoming remains difficult. The Attorney-General must place weight on such unknown factors as the Flag State's consent, and the views of the international community. Whether jurisdiction can be safely enforced in any particular situation therefore remains uncertain.

Such uncertainty may have undesirable ramifications for enforcement. So that enforcement agencies avoid the risk being ostracised by the international community, arrangements may have to be made before taking enforcement measures. The AttorneyGeneral may be consulted, the Flag State notified and the international waters tested before action is taken. While such an approach avoids infringing international interests, it makes the assertion of extra-territorial jurisdiction cumbersome. There is a real possibility that the offender may have left New Zealand before any enforcement measures can be taken.

The consent of the Attorney-General is therefore not a perfect solution. While it ensures that prosecutions will be made consistently with international law, it does not offer the same security for other enforcement measures. Given that such measures usually precede prosecution, this is important if New Zealand's extra-territorial jurisdiction is to be asserted effectively over crimes on the high seas.

\section{B Judicial Interpretation}

Interpreting the jurisdictional provisions so as to gloss a limitation that the provisions only give jurisdiction so far as it is consistent with international law may provide more certainty than reliance on the Attorney-General. By clearly delimiting the extent to which jurisdiction may be enforced, enforcement within those limits becomes more certain and hence more likely. If no international basis for asserting jurisdiction exists, enforcement

54 The exception is where the journey is a "round trip" from a New Zealand port without having entered any foreign port. 
measures could not be contemplated. Such an interpretation would also improve the role of the Attorney-General in the process to one of implementing comity with other States.

In that this argument requires a departure from the legislation that is clear, it goes against the grain of common law tradition. ${ }^{55}$ The Court in Sellers v Maritime Safety Inspector emphasised the need to read legislation affecting maritime matters consistently with international law if it could be done.

Three readings that would have removed the conflict between domestic and international law were argued in Sellers. The Court rejected two because the provisions could not be read in the manner argued. One of the arguments rejected in Sellers was a reading of "a pleasure craft" as "a New Zealand pleasure craft" as "the usage throughout the Act denie[d] that possibility". ${ }^{56}$ A similar argument on section $8(1)$ (c) would also likely fail, as nationality-based jurisdiction is already provided for by sections $8(1)$ (a) and (d): reading section $8(1)(c)$ as asserting only nationality-based jurisdiction would render it superfluous, and contrary to Parliament's intent.

If a nationality-based restriction cannot be read into section 8 , the Court might still consider reading a more general gloss into the provisions so that assertions of extraterritorial jurisdiction would be limited by the current boundaries of international law.

Again, this approach must be seen as leaving the words of the statute far behind. However, some support for this interpretation must be gained from the Court of Appeal's apparent endorsement of the United States Supreme Court decision in Lauritzen v Larsen ${ }^{57}$ and in particular Justice Jackson's endorsement in that case of the earlier decision in United States $v$ Palmer. The Court in Palmer held that an extra-territorial criminal provision that contemplated the punishment of "any person" could not contemplate every human being and had to be "limited to cases within the jurisdiction of the state". ${ }^{58}$

The endorsement by the Court of Appeal of Palmer is particularly relevant as Palmer was not contemplating a distinction based on whether the person was a national of the state, but a distinction based on the location of the person. ${ }^{59}$ Hence, the alternatives were not between straight literalism and an interpretation based on the limits of the nationality

55 Salomon v Commissioners of Customs and Excise [1967] 2 QB 116 (CA)

56 Sellers, above n 3, 59 per Keith J.

57 Lauritzen $v$ Larsen (1953) 345 US 571 per Jackson J.

58 United States v Palmer (1818) 16 US 610, 631 per Marshall CJ; see Sellers, above n 10, 59 per Keith J.

59 See Lauritzen $v$ Larsen, above n 56, 577 per Jackson J. 
principle, but between literalism and a wider, general restriction: a situation comparable with the interpretation of section 8 .

It is difficult to predict how the Court of Appeal might reconcile this finely balanced point. The latter approach is perhaps the more likely, given the Court's apparent willingness to read provisions with extra-territorial effect consistently with international law. However, it must be recognised that such an approach requires the stretching of the wording of the provisions.

Moreover, such an interpretation can not reconcile all the jurisdictional difficulties of the Crimes Act. The essential ambiguity of international law remains. Judicial interpretation merely shifts consideration of the scope of international law away from the Attorney-General. While this may remove the uncertainty that is associated with predicting the decision of the Attorney-General, the uncertainty concerning the prescriptive grounds in international law remains. This uncertainty may decrease over time as precedent grows. However, this is unlikely given the variable nature of international law and the fact that precedent forming cases are likely to be rare.

It is suggested, therefore, that judicial interpretation and the role of the AttorneyGeneral do not provide a complete answer to the problems with the extra-territorial jurisdiction asserted by the Crimes Act identified by this paper. They do not fix the holes in the Crimes Act net. At best, they can usually prevent the net being cast in violation of international law, although there remains the difficulty of enforcement within New Zealand waters. Ultimately, legislative reform is arguably required to remedy some of the defects inherent in the jurisdictional provisions. However, the extent to which remedial legislation is desirable is more problematic.

\section{Legislative Reform}

There can be little question that some reform of the Crimes Act is required. At the very least, the Crimes Act should be amended to implement New Zealand's withdrawal from the 1931 British Commonwealth Merchant Shipping Agreement. It must be accepted that assertions of jurisdiction over all British subjects and Commonwealth ships are no longer legitimate. Also, there can be little argument that section 8(3) no longer represents an acceptable assertion of jurisdiction in international law and should be removed from the Act. The Crimes Bill 1989, introduced to reform the Crimes Act 1961 but never passed, remedied both these historical oversights. ${ }^{60}$

These, however, would be cosmetic changes, leaving the jurisdiction asserted by the Crimes Act largely unchanged. Further reform may also be desirable. First, as was argued

60 Crimes Bill 1989, no 152-1, cl 14. 
earlier in this paper, the nationality-based jurisdiction currently asserted by the Crimes Act has two important gaps. The provisions do not cover nationals who commit offences whilst in the water, nor nationals who commit offences on board ships to which they belong. The latter arguably operates to effectively prevent New Zealand asserting jurisdiction over protest incidents on the basis that those involved are New Zealand citizens. Neither of these gaps can be remedied by either judicial interpretation or through the role of the Attorney-General. However, legislative reform provides a beguilingly simple solution. A direct assertion of jurisdiction over New Zealand nationals who commit crime while on the high seas could remedy both gaps, by disposing of the requirements that (a) the crimes be committed on board a ship and (b) that, where the crime occurred on board a foreign ship, the New Zealand national over whom jurisdiction is asserted does not belong to the ship. Both changes would be consistent with international law.

These changes aim to bring domestic legislation in line with international law, where such law is readily definable. A more problematic question is whether more complete reform of the jurisdictional provisions is either necessary or desirable.

Although it might be argued that the Act should contain substantive provisions that amount to a direct assertion of such jurisdiction as may be exercised in international law, this raises the obvious practical objection that the relevant international law is in itself uncertain. A practical approach to jurisdiction may be preferred over a rigid formulation of an area of international law that is inherently difficult. Definition is not the problem: concepts such as passive personality jurisdiction are relatively easy to formulate. Rather, the difficulty arises over the extent to which each particular basis for jurisdiction may be asserted. The acceptance of particular grounds by the international community is relatively fluid. If it is to ensure continued consistency with international law, a rigid formulation must assert jurisdiction well within the boundaries of what is permissible. A rigid formulation that attempts to assert a wider jurisdiction runs a dual risk as international acceptance of particular grounds ebbs and flows of being considered at times too narrow and at others too wide. A "narrow" provision is unacceptable for a state attempting to assert the maximum influence it can over protest incidents. A "wide" provision is prone to the same difficulties as exist with the current legislation. A rigid formulation is, if it is to be enforced consistently with international law, prone to either uncertainty or inadequacy.

A practical provision such as section $8(1)(c)$ does not suffer from such difficulties. Moreover, it is clear that the Courts have accepted that "some legislation is capable of having a varying application, even without express amendment, following the 
development of relevant rules of international law". ${ }^{61}$ In Sellers the Court was comfortable that "the day-to-day (or at least year-to-year) meaning of national law may vary without formal change." 62

What then of certainty? If a practical, but uncertain, provision is to be preferred, this may mean that extra-territorial jurisdiction may rarely be enforced. However, such an argument rests on an assumption that any uncertainty will always be resolved in favour of not risking offending the international community. This is a question of the attitude of enforcement officers, not of the legislative provisions.

It may be that, since any legislative intervention is somewhat unlikely, even if it could solve the current difficulties, what is required is a change of attitude towards enforcement. Any assertion of jurisdiction over protest incidents on the high seas involves a balance. While it is desirable that New Zealand asserts as wide a jurisdiction as possible, so as to best influence the actors in protest situations, it is also desirable that New Zealand does not infringe its UNCLOS obligations, or unduly antagonise the international community. However, adopting a stance that the latter factors will always prevail over the desirability of sanctions in cases of doubt is not a balance.

It is suggested in this regard that while significant weight should be given to the possibility of negative reaction from the international community, it should not always act as the ultimate trump card. There may be situations where it is appropriate to aggressively assert extra-territorial jurisdiction, for instance where the ship on which the offence took place flies a flag of convenience, or that of a country that routinely ignores crimes committed at sea. That such a situation can occur is evidenced by United States $v$ Roberts. The case involved an attempted rape on board a cruise ship. On accepted grounds in international law, the United States of America, the prosecuting state, had little legal connection with the offence. Yet in that case, prosecution by the state to which the ship returned at the end of the voyage during which the crime was committed was clearly appropriate. Neither the Flag State (Liberia) nor the offender's home country showed an interest in prosecuting what was obviously a serious harm. ${ }^{63}$ In order to deter future crimes and punish the offender, it was important that the offence was not lost between the jurisdictional cracks.

This is not advocating an "enforce first, ask questions later" policy. Enforcement should only take place when there appear to be grounds in international law for New Zealand to

61 Sellers, above n 3, 61 per Keith J.

62 Sellers, above n 3, 62 per Keith J.

63 United States $v$ Roberts, above n 19, 608 per Vance J. 
enforce jurisdiction over protest incidents. Rather, it is suggested that a more balanced approach to asserting jurisdiction is appropriate. It may be, in certain cases, that it is worth risking a possible negative reaction from the international community for a more proactive enforcement policy. This may mean more assertions of jurisdiction on the less accepted grounds of jurisdiction, such as the passive personality principle, or of the wider limb of the universality principle. A shift in the balance maintained between the need for consistency with international law and the ability to provide a meaningful deterrent for violent protest incidents is required.

\section{CONCLUSION}

This paper has sought to cast some light on New Zealand's current legislative armoury for asserting extra-territorial jurisdiction over protest incidents at sea. In particular, two instruments have been analysed, the Crimes Act 1961 and the Maritime Crimes 1999.

Of the two, the Maritime Crimes Act provides the more stable basis for asserting extraterritorial jurisdiction. However, the Maritime Crimes Act will only cover the most serious of protest incidents. The Crimes Act addresses a far broader range of offences. It is therefore essential, if New Zealand is to attempt to deter those who would disturb the peace of the high seas, that the Crimes Act provides effective assertions of extra-territorial jurisdiction. The tug is, perhaps, more necessary than the super-yacht.

Moreover, if the Crimes Act is a little rusty, it does not follow that it is wholly ineffective. International law cannot be ignored. Yet the uncertainty surrounding the ability to assert extra-territorial jurisdiction in international law in specific circumstances ultimately provides the major obstacle to asserting an effective deterrent jurisdiction over protest incidents. The current, practical approach to extra-territorial jurisdiction which avoids reference to less certain grounds of jurisdiction but allows them to be asserted if necessary is perhaps the best compromise.

If the status quo is to be maintained, it does not have to follow that protest incidents must remain outside New Zealand's net. A more pro-active enforcement policy that adopted a fairer balance between the competing interests of consistency and maximising the deterrent effect is both possible given the current legislative context, and, in the author's opinion, desirable.

However, if current trends continue, it is unlikely that either the Crimes Act or the Maritime Crimes Act will be unsheathed on any regular basis. Extra-territorial matters have a habit of being "out of sight, out of mind". ${ }^{64}$ However, with incidents like that involving the Nisshin-maru becoming more frequent and more widely publicised, it is

64 Shields, above n 26. 
possible that extra-territorial incidents will start to venture into the sight and minds of the public. Hopefully, it will not require a calamity on the scale of the Achille Lauro to catalyse effective sanctions against those would commit acts of violence upon the high seas. 